\title{
The Relationship between Knowledge, Information Sources, Family Support and Implementation of Provider- Initiated Testing and Counseling in Pregnant Woman
}

\author{
Hubungan antara Pengetahuan, Sumber Informasi, Dukungan Keluarga dan Perilaku Pemeriksaan \\ Provider-Initiated Testing and Counseling pada Ibu Hamil
}

\begin{abstract}
Uci Ciptiasrini*
Midwifery Study Program, Sekolah Tinggi IImu Kesehatan Indonesia Maju, Jalan Harapan No.50, Lenteng Agung, Jagakarsa, South Jakarta, Jakarta, Indonesia.
\end{abstract}

DATA OF ARTICLE:

Received: 13 Sep 2019

Reviewed: 1 Nov 2019

Revised: 1 Dec 2019

Accepted: 11 Jan 2020

*CORRESPONDENCE:

uci.stikim@gmail.com

DOI:

10.18196/mm.200139

TYPE OF ARTICLE: Research

\begin{abstract}
The discovery of cases of HIV and AIDS at the age of under four years old in Indonesia indicates that there is still HIV transmission from mother to child. This study aims to identify the relationship between knowledge, information sources, family support, and the implementation of Provider-Initiated Testing and Counseling (PITC) examinations in pregnant women. This research was analytic descriptive with a cross-sectional approach conducted in August 2018, with 85 respondents selected by accidental sampling. The population in this study were all pregnant women who visited the community health center. Data was collected by giving questionnaires directly to respondents. Relationships between variables were tested with chi-square analysis. The results showed that $36(62.1 \%)$ respondents have good behavior and good knowledge, and the chi-square test results obtained $\mathrm{p}$ value $=0.025$. Thirty $(68.2 \%)$ respondents have good behavior and have access to information sources and $p$-value $=0.007$. Thirty-three $(67.3 \%)$ respondents have good behavior and have family support with the p-value $=0.004$. It can be concluded that there is a relationship between knowledge, information sources, family support, and the implementation of the PITC examination of pregnant women.
\end{abstract}

Keywords: Family Support; HIV/AIDS; Knowledge; PITC; Pregnant woman

Abstrak: Penemuan kasus HIV dan AIDS pada usia di bawah 4 tahun di Indonesia menandakan masih ada penularan HIV dari ibu ke anak. Penelitian ini bertujuan untuk mengetahui hubungan antara pengetahuan, sumber informasi, dukungan keluarga terhadap perilaku pemeriksaan Provider-Initiated Testing and Counseling (PITC) pada ibu hamil. Penelitian ini bersifat deskriptif analitik dengan pendekatan cross sectional dilakukan pada bulan Agustus Tahun 2018, dengan 85 responden yang dipilih dengan cara accidental sampling. Populasi dalam penelitian ini adalah seluruh ibu hamil yang melakukan kunjungan ke Puskesmas. Pengumpulan data dilakukan dengan memberikan kuesioner langsung kepada responden. Hubungan antar variabel diuji dengan analisis chi square. Hasil penelitian menunjukkan bahwa sebanyak $36(62,1 \%)$ responden memiliki perilaku baik dan pengetahuan baik dengan hasil uji statistik chi square diperoleh nilai pValue $=0,025$. sebanyak $30(68,2 \%)$ responden memiliki perilaku baik dan mendapatkan sumber informasi dengan nilai $p$-Value $=0,007.33(67,3 \%)$ responden memiliki perilaku baik dan mendapat dukungan keluarga dengan $p-V a l u e=0,004$. Kesimpulan ada hubungan antara Pengetahuan, sumber informasi dan dukungan keluarga terhadap perilaku pemeriksaan PITC ibu hamil.

Kata Kunci: Dukungan keluarga; HIV/AIDS; Pengetahuan; PITC; Wanita hamil 


\section{INTRODUCTION}

HIV / AIDS is a health problem throughout the world, including in Indonesia. Since it has been initially discovered until June 2018, HIV / AIDS has reached $433(84.2 \%)$ of 514 districts/cities in 34 provinces in Indonesia. The cumulative number of HIV infections identified by June 2018 was 301,959 people ( $47 \%$ of the estimated total of people with HIV AIDS in 2018 were 640,443 people), and most were found in the age group of 25-49 years old and 20-24 years old. The provinces with the highest number of HIV infections were DKI Jakarta $(55,099)$, followed by East Java (43,399), West Java $(31,293)$, Papua (30,699), and Central Java $(24,757) .{ }^{1}$

Pregnant women who have human immunodeficiency virus HIV/AIDS have the potential to transmit the disease to babies at birth. Therefore, it is important to understand the status of HIV/AIDS in pregnant women to prevent transmission. Data from the Ministry of Health (Kemenkes), in 2018, HIV showed that it was only about $13.38 \%(761,373)$ of the total number of pregnant women in Indonesia, which is equal to $5,291,143$ people who have infected HIV / AIDS. Out of the total number of people who underwent the test, 2,955 people were found to be HIV positive. Meanwhile, 893 pregnant women received antiretroviral drug therapy to reduce the viral load $(\mathrm{VL}){ }^{2}$ Enforcement of HIV status in pregnant women as early as possible is crucial to prevent HIV transmission in infants because mothers can immediately get antiretroviral (ARV) treatment, psychological support, and information about HIV/AIDS called an HIV screening test through Provider-Initiated Testing and Counseling (PITC). ${ }^{3}$ Provider-Initiated Testing and Counseling refers to health care providers with an extensive approach to someone who is vulnerable and at risk of voluntarily conducting a test. The results of this test are needed to find out whether the patient is infected or not. 4

Depok City Health Office noted that people with Human Immunodeficiency Virus (HIV) in Depok City experienced a sharp increase from year to year. According to the data in Depok City Health Office, in 2014, it found 86 cases of people living with HIV. Furthermore, there were 146 cases in 2015 and 278 cases in 2016. Every time the public health center (PHC) found a patient of HIV / AIDS, the PHC examine the CD4 or white blood cells to identify what percentage of the cells as a measure of the patient's immune system. After that, referrals will be made to the Care Support and Treatment services of Depok City General Hospital or Sentra
Medika Hospital to get antiretroviral (ARV) treatment. According to the Secretary of the Depok City Education Office, people living with HIV tend to be icebergs. ${ }^{5}$ Based on data obtained from the Sukmajaya Depok Public Health Center, the total number of pregnant women in the Sukmajaya Depok Public Health Center working area in 2015 was 1,823 pregnant women. In 2016 it increased into 1,826 pregnant women, 1,864 pregnant women in 2017, and 960 pregnant women in 2018 from January to June. As the data for pregnant women in 2015 showed 589 people who performed PITC, in 2016, 667 pregnant women conducted PITC with the results of four HIV positive people. Furthermore, in 2017922 pregnant women performed the examination and 586 pregnant women in 2018 from the month January to June. It interesting to identify the relationship between knowledge, information sources, social support, and implementation of PITC in pregnant women.

\section{MATERIALS AND METHOD}

The research is a quantitative analytical survey with a cross-sectional design. The data obtained by distributing valid questionnaires with $r$ table $>0.444$ to pregnant women who carried out PITC at the Sukmajaya Depok Public Health Center in 2018. The data collection used an accidental sampling technique and obtained 85 respondents. Furthermore, the data is processed using bivariate analysis through the chi-square test. The inclusion criteria of the research include pregnant women in Sukmajaya Depok Public Health Center who have PITC check-up. Meanwhile, the exclusion criteria include inappropriate common characteristics subject of the study from a population target such as illiterate pregnant women who refused to be sampled.

The implementation of PITC is a counseling activity and HIV testing suggested by the health services to pregnant women who come to the health service center. There are two types of PITC activities, such as the PITC test initiated by the respondents and the one suggested by the health center. Knowledge about PITC check-up is needed by the pregnant women whose process emerges from identifying, understanding, listening, feeling, and thinking. They must understand why she has to undergo the PITC test and also understands the definition and the functions of PITC. Any sources have been used for pregnant women to obtain any information about the PITC, for example, newspaper, electronic media, and the information from the health worker. Encouragement to 
pregnant women given by the family to conduct PITC is such emotional support.

\section{RESULT}

Table 1. shows that total of 45 (52.9\%) pregnant women had the initiative in conducting the PITC examination, $68.2 \%$ (58 people) of pregnant women had adequate knowledge, $51.8 \%$ (44 people) of them received adequate information about PITC, and 57.6\% (49 people) of pregnant women were supported by their families.

Table 2 showed that $p$-value in each variable was <0.05, that is 0.025 in the variable of knowledge, 0.007 in the variable of information sources, and 0.004 in the variable of family support. It indicates that there is a relationship between knowledge, information sources, and family support in the implementation of PITC examinations in pregnant women in the Sukmajaya Sub-District Depok Health Center in 2018.

Table 1 Distribution and frequency between knowledge, information sources, family support and the implementation of PITC in pregnant women in the Sukmajaya Sub-District Depok Health Center in 2018

\begin{tabular}{lll}
\hline Variable & f & (\%) \\
\hline PITC Screening & & \\
Initiated by the respondents & 45 & 52.9 \\
Suggested by the health center & 40 & 47.1 \\
Knowledge & & \\
Adequate knowledge & 58 & 68.2 \\
Inadequate knowledge & 18 & 31.8 \\
Information sources & & \\
Adequate information & 44 & 51.8 \\
Inadequate Information & 41 & 48.2 \\
Family support & & \\
Supported & 49 & 57.6 \\
Unsupported & 36 & 42.4 \\
\hline
\end{tabular}

Table 2 The Relationship between Knowledge, Information sources, Family Support and the implementation of PITC examination in pregnant women in Sukmajaya Depok Health Center in 2018

\begin{tabular}{|c|c|c|c|c|c|c|}
\hline \multirow{3}{*}{ Variable } & \multicolumn{4}{|c|}{$\begin{array}{c}\text { PITC Screening } \\
\text { Result }\end{array}$} & \multirow{3}{*}{ P-value } & \multirow{3}{*}{ OR } \\
\hline & \multicolumn{2}{|c|}{ Good } & \multicolumn{2}{|c|}{$\begin{array}{c}\text { Disatisfac } \\
\text { tory }\end{array}$} & & \\
\hline & $\bar{F}$ & $\%$ & $\mathrm{~F}$ & $\%$ & & \\
\hline \multicolumn{7}{|l|}{ Knowledge } \\
\hline Adequate & 36 & 62.1 & 22 & 37.9 & 0.025 & 3.273 \\
\hline Inadequate & 7 & 38.9 & 11 & 61.1 & & \\
\hline \multicolumn{7}{|c|}{ Information Sources } \\
\hline Adequate & 30 & 68.1 & 14 & 31.8 & 0.007 & 3.714 \\
\hline Inadequate & 45 & 36.6 & 26 & 63.4 & & \\
\hline \multicolumn{7}{|c|}{ Family support } \\
\hline Supported & 33 & 67.3 & 16 & 32.7 & 0.004 & 4.125 \\
\hline Unsupported & 12 & 33.3 & 24 & 66.7 & & \\
\hline
\end{tabular}

\section{DISCUSSION}

The relationship of knowledge and the implementation of PITC examination in pregnant women

Knowledge is derived from the result of the human senses, or the results to an object through their senses (eyes, nose, ears, etc.). At the time of sensing to produce knowledge, it is greatly influenced by the intensity of attention and perception of the object. Most people's knowledge is obtained through the hearing (ear), and senses of sight (eyes). ${ }^{6}$ The results of this study showed that 36 respondents $(62.1 \%)$ had adequate knowledge. It was in line with the result of another research showing that 36 respondents with adequate knowledge conducted PITC check-up (62.1\%), and seven respondents with inadequate knowledge conducted PITC (38.9\%). The results of the analysis showed there is a relationship between knowledge and PITC in pregnant women with $\mathrm{p}$-value $=0.025$ (Table 2).

The researchers' assumption is based on the results that knowledge has an important role in the implementation of PITC examination. If pregnant women lack knowledge, they can hardly understand the implementation of PITC examination. The value odd ratio 3,273 can conclude that pregnant women with the inadequate knowledge showed by the value mentioned above are less likely to understand well on PITC check-up compared to those who have adequate knowledge. The result in line with the research by Fatimah (2015), ${ }^{7}$ that 50 respondents who have adequate knowledge carried out the examination (69.4\%), while 21 respondents examined with inadequate knowledge (29.1\%).

The relationship of information sources and the implementation of PITC examination in pregnant women

The need for accurate data or information increases, but the current information system still cannot produce accurate, complete, and timely data. Various problems are still encountered in the implementation of health information systems, including the absence of the same perception among health providers, especially organizers for health information systems. ${ }^{8}$ The results of the study noted that 30 respondents have adequate knowledge and information sources (68.2\%), while 14 respondents have inadequate knowledge and information (31.8\%). It is in line with the research conducted at Mantrijeron and Sleman Public Health Centers, which showed that $79.6 \%$ of respondents need more information to conduct HIV tests. ${ }^{9}$ It indicates that the source of information has a vital 
role in the implementation of the PITC. If the source of information is inadequate, then it can influence the implementation of PITC itself against pregnant women.

\section{The relationship between family support and the implementation of the PITC examination in pregnant women}

Family is the smallest unit of society consisting of a leader and several people who live in the same place and interdependence and that they are likely to provide physical needs and health care. Health care and healthy practices (which affect the health status of individual family members) are the most relevant parts of the health care function. ${ }^{10}$ The results of the study note that 33 respondents have adequate knowledge and family support $(67.3 \%)$ while 16 respondents have inadequate knowledge and family support (32.7\%). ${ }^{11}$ Chi-square analysis resulted in the value of statistical $p$ value $=0,004$, that it denotes that there is a correlation between family encouragement and significant implementation of the PITC for pregnant women.

The result of Odd Ratio is 4,125 , it means that pregnant women unsupported by the family had the 4,125 times the opportunity to behave unwell to the PITC compared to the ones who get support from the family. It indicates that family support plays a vital role in identifying if the person obtains emotional support. The results of this study concluded that support from spouse or family members has a significant favorable influence on the willingness of pregnant women to carry out the PITC test. In other words, the better the support from a spouse or family member is, the more the willingness of pregnant women to conduct the PITC test will be. ${ }^{12}$

In addition, family support has an important role in the implementation of the PITC examination. If it lacks family support, it can influence the implementation of the PITC examination on pregnant women.

\section{CONCLUSION}

There is a relationship between knowledge, information sources, and family support and the implementation of the PITC examination in pregnant women in the Sukmajaya Depok Public Health Center in 2018.

\section{REFERENCES}

1. Komisi Penanggulangan AIDS. Hari AIDS Sedunia 2014. [Internet]. Hari AIDS Sedunia,
Momen STOP Penularan HIV: Saya Berani, Saya Sehat! 2014. [cited 2019 May 23]. from: http://www.aidsindonesia.or.id/news/6152/1/12 /09/2014/Hari-AIDS-Sedunia-2014

2. Rimawi, B. H., Johnson, E., Rajakumar, A., Tao, S., Jiang, Y., Gillespie, S., ... \& Chakraborty, R. Pharmacokinetics and placental transfer of elvitegravir, dolutegravir, and other antiretrovirals during pregnancy. Antimicrobial agents and chemotherapy, 2017, 61(6), e02213-16.

3. Kemenkes, R. I. Pedoman Nasional Pencegahan Penularan HIV Dari Ibu Ke Anak (PPIA). Edisi Kedua. Jakarta: Kementerian Kesehatan. 2012.

4. Fikadu, D., Dejene, T., Assegid, S., \& Shegaze, M. Assessment of Utilization of Provider Initiated HIV Testing and Counseling and Associated Factors among Adult Out Patient Department Patients in Wonchi Woreda, South West Shoa Zone, Central Ethiopia. J Infect Dis Ther, 2016, 4(276), 2332-0877.

5. Purwaningsih, S. S., \& Widayatun, N. F. N. Perkembangan HIV dan AIDS Di Indonesia: Tinjauan Sosio Demografis. Jurnal Kependudukan Indonesia, 2008, 3(2), 75-95.

6. Notoatmodjo, S. Promosi Kesehatan, Teori \& Aplikasi, ed. revisi 2010. Jakarta: Penerbit Rineka Cipta. 2010

7. Fatimah, F., \& Hati, F. S. (2015). Tingkat Pengetahuan Ibu Hamil tentang HIV/AIDS dengan Perilaku Pemeriksaan Test PITC (Provider Initiated Test and Counselling) di Puskesmas Sleman Yogyakarta. Jurnal Ners dan Kebidanan Indonesia, 3(1), 48-52.

8. Kemenkes. R. I. Roadmap Sistem Informasi Kesehatan Tahun 2011-2014. Jakarta: Pusat Data Dan Informasi, Kemenkes RI. 2014; (1):1-5.

9. Setiyawati, N., \& Meilani, N. Determinan Perilaku Tes HIV pada Ibu Hamil. Kesmas: National Public Health Journal, 2015, 9(3), 201-206.

10. Antonucci, T. C., Berkman, L., Börsch-Supan, A., Carstensen, L. L., Fried, L. P., Furstenberg, F. F., $\ldots \&$ Rother, J. Society and the Individual at the Dawn of the Twenty-First Century. In Handbook of the Psychology of Aging (pp. 41-62). Academic Press. 2016.

11. Arianty, T. D. Perilaku Ibu Hamil dalam Melakukan Tes HIV. HIGEIA (Journal of Public Health Research and Development), 2018, 2(3), 488. 497.

12. Sayuti, S., \& Mulyarini, P. Hubungan Pengetahuan Ibu Hamil Tentang HIV/AIDS, Dukungan Keluarga, dan Kunjungan ANC dengan Kesediaan Ibu Untuk Melakukan Tes PITC di Wilayah Kerja Puskesmas Ketawang, Kabupaten Malang. Biomed Science, 2019, 6(1), 43-52. 